\title{
PENGARUH KECERDASAN EMOSI DAN KECERDASAN SPIRITUAL TERHADAP KINERJA PEGAWAI BALAI DIKLAT APARATUR KEMENTERIAN KELAUTAN DAN PERIKANAN
}

THE INFLUENCE OF EMOTIONAL QUOTIENT AND SPIRITUAL QUOTIENT TO OFFICER PERFORMANCE ON TRAINING OFFICE OF APPARATUS MINISTRY OF MARINE AFFAIRS AND FISHERIES

\author{
Yudistira Adi Nugroho \\ Balai Diklat Aparatur Kementerian Kelautan dan Perikanan \\ Jl. Raya 2 Sukamandi, Ciasem 41256, Subang-Jawa Barat \\ Email: yudistiraadinugroho09@gmail.com
}

\begin{abstract}
The results of the evaluation of training implementation shows the performance of employees who are still not optimal. Several factors causing the cause of emotional and spiritual quotient of employees who are still low. This study aims to obtain empirical evidence and obtain clarity of phenomena and conclusions about the influence of emotional and spiritual quotient on the performance of personnel Training Office Apparatus Ministry of Marine Affairs and Fisheries either partially or simultaneously.

For research purposes, the method used in this study consists of descriptive and verification methods. Data collection is done by field research, through the spread of questionnaires that are structured using Likert scale. Data analysis to describe each variable using scale range analysis. While to describe the influence of emotional and spiritual quotient on employee performance by using path analysis.

The results showed: 1) Emotional Quotient is in the high scale, spiritual quotient is in the high scale, and employee performance is in the high-scale range, 2) Emotional and spiritual quotient partially influential On employee performance of Training Office for Apparatus Ministry of Marine Affairs and Fisheries, and 3) Emotional and spiritual quotient simultaneously affect the performance of personnel Training Office for Apparatus Ministry of Marine Affairs and Fisheries with the amount of $63,46 \%$.
\end{abstract}

Keywords: Emotional Quotient, Spiritual Quotient, Employee Performance

\begin{abstract}
ABSTRAK
Hasil evaluasi penyelenggaraan diklat menunjukkan kinerja pegawai yang masih belum optimal. Beberapa faktor penyebab diduga karena kecerdasan emosi dan kecerdasan spiritual pegawai yang masih rendah. Penelitian ini bertujuan untuk memperoleh bukti-bukti empiris dan memperoleh kejelasan fenomena serta kesimpulan tentang pengaruh kecerdasan emosi dan kecerdasan spiritual terhadap kinerja pegawai Balai Diklat Aparatur Kementerian Kelautan dan Perikanan baik secara parsial maupun secara simultan.

Untuk keperluan penelitian, metode yang digunakan pada penelitian ini terdiri dari metode deskriptif dan verifikatif. Pengambilan data dilakukan dengan cara penelitian lapangan, melalui penyebaran kuisioner yang terstruktur menggunakan
\end{abstract}


skala likert. Analisis data untuk menggambarkan masing-masing variabel menggunakan analisis rentang skala. Sedangkan untuk menggambarkan pengaruh kecerdasan emosi dan kecerdasan spiritual terhadap kinerja pegawai dengan menggunakan analisis jalur.

Hasil penelitian menunjukkan : 1) Kecerdasan emosi berada pada rentang skala tinggi, kecerdasan spiritual berada pada rentang skala tinggi dan kinerja pegawai berada pada rentang skala tinggi, 2) Kecerdasan emosi dan kecerdasan spiritual secara parsial berpengaruh terhadap kinerja pegawai Balai Diklat Aparatur Kementerian Kelautan dan Perikanan, dan 3) Kecerdasan emosi dan kecerdasan spiritual secara simultan berpengaruh terhadap kinerja pegawai Balai Diklat Aparatur Kementerian Kelautan dan Perikanan dengan besaran 63,46 \%.

Kata Kunci: Kecerdasan Emosi,Kecerdasan Spiritual, Kinerja pegawai

\section{PENDAHULUAN}

Pelayanan prima menjadi satu hal yang mendasar sebagai tolok ukur keberhasilan pemerintah dalam menyelenggarakan negara. Pelayanan prima yang diberikan pemerintah kepada masyarakat dapat diindikasikan dengan pelayanan yang cepat, murah, tidak berbelit-belit dan transparan. Namun untuk mewujudkan pelayanan prima yang diharapkan oleh masyarakat masih menjadi satu hal yang sulit untuk diwujudkan. Dalam beberapa sektor masih ditemukan permasalahan dalam pelayanan pemerintah. Hal ini dibuktikan dengan masih banyaknya keluhan yang disampaikan masyarakat baik melalui media elektronik maupun media sosial. Dengan jumlah penduduk yang besar dan wilayah yang luas menjadikan tantangan tersendiri bagi pemerintah dalam memberikan pelayanan prima kepada seluruh masyarakat. Guna memastikan semua hal tersebut dapat terwujud maka pemerintah telah mengeluarkan Undang - Undang Nomor 25 tahun 2009 tentang pelayanan publik. Dalam UU tersebut dinyatakan bahwa pelayanan publik sebagai kegiatan atau rangkaian kegiatan dalam rangka pemenuhan kebutuhan pelayanan sesuai dengan peraturan perundang-undangan bagi setiap warga negara dan penduduk atas barang, jasa, dan / atau pelayanan administratif yang disediakan oleh penyelenggara pelayanan publik. Untuk mewujudkan pelayanan yang berkualitas maka dibutuhkan Aparatur Sipil Negara (ASN) yang profesional. ASN yang profesional ditandai dengan memiliki kemampuan berpikir dan berperilaku menyikapi kepentingan masyarakat dengan lebih baik dan berkualitas. Kemampuan tersebut tentunya dapat memberikan manfaat dalam rangka menghasilkan kinerja terbaik bagi organisasi.

Balai Diklat Aparatur Kementerian Kelautan dan Perikanan sebagai lembaga penyelenggara diklat bagi aparatur di Kementerian Kelautan dan Perikanan terus berupaya untuk memberikan pelayanan yang maksimal bagi para peserta diklat. Namun dari hasil rekapitulasi penilaian Indeks Kepuasan Peserta Diklat (IKPD) merefleksikan kinerja pegawai yang belum maksimal. Selama tiga tahun terakhir yakni tahun 2015 s.d 2017, penilaian yang diberikan peserta diklat terhadap aspek pelayanan menunjukkan belum optimalnya kinerja pegawai. Sesuai laporan hasil evaluasi penyelenggaraan diklat diketahui bahwa kinerja pegawai dalam penyelenggaraan diklat belum mencapai nilai rata-rata sangat memuaskan. Data rekapitulasi hasil evaluasi penyelenggaraan diklat pada tahun 2015 s.d 2017 adalah sebagai berikut : 
Tabel 1. Rekapitulasi Hasil Evaluasi Penyelenggaraan Diklat

\begin{tabular}{|c|l|c|c|c|}
\hline \multirow{2}{*}{ No } & \multirow{2}{*}{ Kualifikasi } & \multicolumn{3}{|c|}{ Tahun } \\
\cline { 3 - 5 } & & $\mathbf{2 0 1 5}$ & $\mathbf{2 0 1 6}$ & $\mathbf{2 0 1 7}$ \\
\hline 1 & Sangat Memuaskan & 1 & 5 & 12 \\
\hline 2 & Memuaskan & 54 & 63 & 48 \\
\hline 3 & Cukup Memuaskan & 4 & 4 & - \\
\hline & Jumlah Diklat & $\mathbf{5 9}$ & $\mathbf{7 2}$ & $\mathbf{6 0}$ \\
\hline
\end{tabular}

Berdasarkan tabel di atas dapat diketahui bahwa dari 59 diklat yang telah dilaksanakan tahun 2015, hanya 1 diklat yang memperoleh penilaian sangat memuaskan, 54 diklat dengan penilaian memuaskan dan 4 diklat dengan penilaian cukup memuaskan. Pada tahun 2016, dari 72 diklat yang telah dilaksanakan hanya 5 diklat yang memperoleh penilaian sangat memuaskan, 63 diklat dengan penilaian memuaskan, dan 4 diklat dengan penilaian cukup memuaskan. Selanjutnya pada tahun 2017 dari total 60 diklat yang dilaksanakan diperoleh penilaian sebanyak 12 diklat dengan kualifikasi sangat memuaskan dan sisanya sebanyak 48 diklat dengan kualifikasi memuaskan.

Hasil evaluasi penyelenggaraan diklat tersebut di atas merupakan dampak dari kinerja pegawai yang masih belum optimal. Salah satu faktor yang mempengaruhi kinerja pegawai adalah kecerdasan emosi. Hasil penelitian Purwanto (2015) menunjukkan bahwa kecedasan emosi berpengaruh secara signifikan terhadap kinerja pegawai. Sehingga dapat dipastikan bahwa dalam tugas pelayanan, kecerdasan emosi dapat mempengaruhi kualitas pelayanan seseorang. Menurut Goleman (2003), kecerdasan emosional sebagai kapasitas dalam mengenali perasaaan-perasaan diri sendiri dan orang lain, dalam memotivasi diri sendiri dan mengelola emosi-emosi dengan baik dalam diri kita sendiri maupun dalam hubungan-hubungan kita. Faktor lain yang juga mempengaruhi kinerja pegawai adalah kecerdasan spiritual. Hasil penelitian Junedi (2016) menunjukkan bahwa kecerdasan spiritual berpengaruh secara signifikan terhadap kinerja pegawai. Kecerdasan spiritual memungkinkan seseorang untuk berpikir kreatif, berwawasan jauh, ikhlas, penuh harapan, membuat atau bahkan mengubah aturan, yang membuat orang tersebut dapat bekerja lebih baik, Nasution (2005:56).

Berdasarkan uraian dan penjelasan yang telah dikemukakan di atas, maka penelitian ini bertujuan untuk : 1) mengukur dan menganalisis bagaimana kecerdasan emosi, kecerdasan spiritual dan kinerja pegawai Balai Diklat Aparatur Kementerian Kelautan dan Perikanan, 2)mengukur dan menganalisis korelasi antara kecerdasan emosi dan kecerdasan spiritual pegawai, 3)mengukur dan menganalisis besaran pengaruh Kecerdasan Emosi dan Kecerdasan Spiritual terhadap Kinerja Pegawai Balai Diklat Aparatur Kementerian Kelautan dan Perikanan.

\section{KERANGKA TEORI}

\subsection{Kecerdasan Emosi}

Cooper dan Sawaf (2002) mendefinisikan kecerdasan emosional adalah kemampuan merasakan, memahami dan secara selektif menerapkan daya dan kepekaan emosi sebagai sumber energi dan pengaruh yang manusiawi. Kecerdasan emosi menuntut pemilikan perasaan untuk belajar mengakui, 
menghargai perasaan pada diri dan orang lain serta menanggapinya dengan tepat, menerapkan secara efektif energi emosi dalam kehidupan sehari-hari. Tentu saja kecerdasan emosional tidak cukup hanya memiliki perasaan. Kecerdasan emosional menuntut kita untuk belajar mengakui dan menghargai perasaan-pada diri kita dan orang lain-dan untuk menanggapinya dengan tepat, menerapkannya dengan efektif informasi dan energi emosi dalam kehidupan dan pekerjaan seharihari.

Agustian (2006), menerjemahkan kecerdasan emosional adalah kemampuan untuk merasa. Kunci kecerdasan emosi adalah pada kejujuran suara hati. Suara hati itulah yang harusnya dijadikan pusat prinsip yang mampu memberi rasa aman, pedoman, kekuatan serta kebijaksanaan. Goleman (2003) menjelaskan bahwa kecerdasan emosional terbagi ke dalam lima wilayah utama, yaitu kemampuan mengenali emosi diri, mengelola emosi diri, memotivasi diri sendiri, mengenali emosi orang lain, dan kemampuan membina hubungan dengan orang lain.

\subsection{Kecerdasan Spiritual}

Kecerdasan seseorang tidak hanya dilihat dari kecerdasan intelektualnya saja akan tetapi juga dari kecerdasan emosi dan kecerdasan spiritualnya. Kecerdasan yang ketiga yaitu kecerdasan spiritual diyakini sebagai kecerdasan yang mampu memfungsikan kecerdasan intelektual dan kecerdasan emosi secara efektif dan kecerdasan spiritual merupakan kecerdasan tertinggi, Zohar dan Marshall (2007). Covey (2005) mendefinisikan kecerdasan spiritual sebagai pusat paling mendasar di antara kecerdasan yang lain, karena dia menjadi sumber bimbingan bagi kecerdasan lainnya. Kecerdasan spiritual mewakili kerinduan akan makna dan hubungan dengan yang tak terbatas. Sedangkan menurut Aziz dan Mangestuti (2006), kecerdasan spiritual meliputi dua aspek yakni kemampuan yang bersifat internal dan eksternal.

\subsection{Kinerja Pegawai}

Kinerja (prestasi kerja) adalah hasil kerja secara kualitas dan kuantitas yang dicapai oleh seseorang dalam melaksankan tugasnya sesuai dengan tanggung jawab yang diberikan kepadanya, Mangkunegara (2005:9). Rivai (2004:309) mengemukakan kinerja karyawan merupakan perilaku yang nyata yang ditampilkan setiap orang sebagai prestasi kerja yang dihasilkan oleh karyawan sesuai dengan perannya dalam perusahaan. Gomes (2003) mengemukakan bahwa terdapat delapan dimensi yang harus diukur secara tepat dalam melakukan penilaian terhadap kinerja pegawai yaitu: Quantity of work, Quality of work, Job knowledge, Creativeness, Coorperation, Dependability Initiative, dan Personal qualities.

Berdasarkan latar belakang penelitian di atas maka dapat diasumsikan bahwa kecerdasan emosi dan kecerdasan spiritual dapat memberikan pengaruh terhadap kinerja pegawai. Untuk memperjelas kerangka berfikir tersebut dapat dilihat pada gambar 1 di bawah ini :

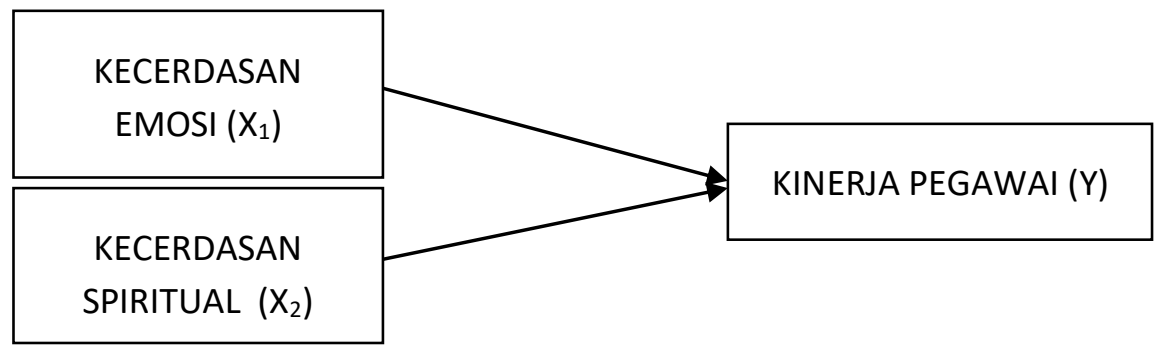




\section{Gambar 1. Kerangka Pemikiran}

Hipotesis dalam penelitian ini adalah sebagai berikut :

1. Terdapat korelasi antara kecerdasan emosi dan kecerdasan spiritual pegawai

2. Terdapat pengaruh kecerdasan emosi dan kecerdasan spiritual secara parsial terhadap kinerja pegawai

3. Terdapat pengaruh kecerdasan emosi dan kecerdasan spiritual secara simultan terhadap kinerja pegawai Balai Diklat Aparatur Kementerian Kelautan dan Perikanan

\section{METODE PENELITIAN}

Metode yang digunakan pada penelitian ini adalah deskriptif verifikatif. Penelitian deskriptif menggambarkan atau menganalisis kondisi setiap variabel. Untuk menggambarkan setiap variabel menggunakan teknik analisis rentang skala. Sedangkan verifikatif dimaksudkan untuk menguji asumsi hipotesis dengan menggunakan perhitungan statistik. Sifat penelitian verifikatif adalah untuk menguji kebenaran dari suatu hipotesis yang dilakukan melalui pengumpulan data dilapangan, dimana dalam penelitian ini akan menguji pengaruh kecerdasan emosi dan kecerdasan spiritual terhadap kinerja pegawai. Teknik yang digunakan untuk menganalisis pengaruh variabel bebas terhadap variabel terikat dengan menggunakan analisis jalur.

Sumber data yang diperlukan untuk menunjang penelitian ini berasal dari hasil studi kepustakaan dan riset dari lapangan. Riset lapangan merupakan sumber data yang diperoleh dari hasil kuisioner yang telah dibagikan kepada pegawai menggunakan skala likert. Untuk populasi yang digunakan pada penelitian ini adalah seluruh pegawai Balai Diklat Aparatur Kementerian Kelautan dan Perikanan yang berstatus PNS sejumlah 48 orang. Sedangkan teknik pengambilan sampel yang digunakan adalah sampel jenuh atau sensus.

Pengujian terhadap instrumen dilakukan dengan uji validitas dan reliabilitas. Uji validitas menunjukkan sejauh mana suatu alat ukur itu mengukur apa yang ingin diukur. Uji reliabilitas dilakukan untuk mengetahui sejauh mana hasil suatu pengukuran dapat dipercaya.

\section{HASIL DAN PEMBAHASAN}

\subsection{Analisis Deskriptif}

\subsubsection{Kecerdasan emosi}

Berdasarkan hasil jawaban responden dapat dilakukan rekapitulasi pada setiap indikator dari variabel kecerdasan emosi. Rekapitulasi tersebut sebagaimana berikut ini:

Tabel 2. Rekapitulasi Jawaban Responden Pada Variabel Kecerdasan Emosi

\begin{tabular}{|c|l|l|c|c|}
\hline No & \multicolumn{1}{|c|}{ Dimensi } & \multicolumn{1}{|c|}{ Indikator } & $\begin{array}{c}\text { Sko } \\
\mathbf{r}\end{array}$ & \multicolumn{1}{|c|}{ Ket. } \\
\hline 1 & $\begin{array}{l}\text { Pengenalan } \\
\text { Diri }\end{array}$ & Pengetahuan terhadap emosi diri & 207 & $\begin{array}{l}\text { Sangat } \\
\text { Tinggi }\end{array}$ \\
\cline { 2 - 5 } & &
\end{tabular}




\begin{tabular}{|c|l|l|c|c|}
\cline { 3 - 5 } & & Kemampuan mengintrospeksi diri & 208 & $\begin{array}{c}\text { Sangat } \\
\text { Tinggi }\end{array}$ \\
\hline 2 & $\begin{array}{l}\text { Pengendalian } \\
\text { Diri }\end{array}$ & Tingkat mengelola emosi & 192 & Tinggi \\
\cline { 3 - 6 } & Kemampuan menanggapi input dari luar & 200 & Tinggi \\
\hline 3 & Motivasi & Tingkat memotivasi diri & 193 & Tinggi \\
\hline 4 & \multirow{2}{*}{ Empati } & $\begin{array}{l}\text { Kemampuan merasakan yang dialami } \\
\text { orang lain }\end{array}$ & 198 & Tinggi \\
\cline { 3 - 6 } & & Kemampuan memberikan solusi & 186 & Tinggi \\
\hline 5 & \multirow{2}{*}{$\begin{array}{l}\text { Keterampilan } \\
\text { Sosial }\end{array}$} & Mampu meyakinkan orang lain & 183 & Tinggi \\
\cline { 3 - 6 } & Mampu menyelesaikan konflik & 183 & Tinggi \\
\hline
\end{tabular}

Sesuai tabel di atas dapat diketahui bahwa indikator pengetahuan terhadap emosi diri, dan indikator kemampuan mengintrospeksi diri berada pada rentang skala 163,5 - 201,9 dengan kategori sangat tinggi. Sedangkan indikator lainnya berada pada rentang skala 202 - 240,4 dengan kategori tinggi. Sehingga rata-rata indikator pada variabel kecerdasan emosi berada pada kategori tinggi. Hal ini bermakna seluruh pegawai di Balai Diklat Aparatur Kementerian Kelautan dan Perikanan memiliki kecerdasan emosi yang memadai untuk menyelesaikan setiap tugas dan tanggung jawabnya dalam pelaksanaan pekerjaan.

\subsubsection{Kecerdasan spiritual}

Berdasarkan hasil jawaban responden dapat dilakukan rekapitulasi pada setiap indikator dari variabel kecerdasan spiritual. Rekapitulasi tersebut sebagaimana berikut ini:

Tabel 3. Rekapitulasi Jawaban Responden Pada Variabel Kecerdasan Spiritual

\begin{tabular}{|c|l|l|c|c|}
\hline No & \multicolumn{1}{|c|}{ Dimensi } & \multicolumn{1}{|c|}{ Indikator } & Skor & Ket. \\
\hline 1 & \multirow{2}{*}{$\begin{array}{l}\text { Kemampuan } \\
\text { internal }\end{array}$} & $\begin{array}{l}\text { Kemampuan berkomunikasi dan } \\
\text { beradaptasi dengan baik }\end{array}$ & 204 & $\begin{array}{c}\text { Sangat } \\
\text { Tinggi }\end{array}$ \\
\cline { 3 - 6 } & $\begin{array}{l}\text { Sikap dan perilaku yang positif terhadap } \\
\text { orang lain }\end{array}$ & 200,5 & Tinggi \\
\cline { 3 - 6 } & $\begin{array}{l}\text { Kemampuan mengatasi permasalahan } \\
\text { eksternal }\end{array}$ & $\begin{array}{l}\text { Tingkat mengembangkan sikap berfikir } \\
\text { yang rasional }\end{array}$ & 192,6 & Tinggi \\
\cline { 3 - 6 } & $\begin{array}{l}\text { Tingkat berusaha memanfaatkan segala } \\
\text { sesuatu dengan baik }\end{array}$ & 197 & Tinggi \\
\cline { 3 - 6 } & $\begin{array}{l}\text { Tingkat kemampuan untuk berbuat } \\
\text { kebaikan }\end{array}$ & 192 & Tinggi \\
\hline
\end{tabular}

Sesuai tabel di atas dapat diketahui bahwa indikator Kemampuan berkomunikasi dan beradaptasi dengan baik mendapatkan skor pada rentang skala 163,5 - 201,9 pada kategori sangat tinggi. Sedangkan indikator lainnya berada pada rentang skala 202 - 240,4 dengan kategori tinggi. Sehingga rata-rata indikator pada variabel kecerdasan spiritual berada pada kualifikasi tinggi. Hal ini bermakna bahwa seluruh pegawai di Balai Diklat Aparatur Kementerian Kelautan dan Perikanan memiliki kecerdasan spiritual yang memadai untuk menyelesaikan setiap tugas dan tanggung jawabnya dalam pelaksanaan pekerjaan.

\subsubsection{Kinerja Pegawai}


Berdasarkan hasil jawaban responden dapat dilakukan rekapitulasi pada setiap indikator dari variabel kecerdasan emosi. Rekapitulasi tersebut sebagaimana berikut ini:

Tabel 4. Rekapitulasi Jawaban Responden Pada Variabel Kinerja Pegawai

\begin{tabular}{|c|c|c|c|c|}
\hline No & Dimensi & Indikator & Skor & Ket. \\
\hline \multirow[t]{2}{*}{1} & \multirow[t]{2}{*}{$\begin{array}{l}\text { Quantity of } \\
\text { Work }\end{array}$} & Pekerjaan selesai tepat waktu & 203 & $\begin{array}{l}\text { Sangat } \\
\text { Tinggi }\end{array}$ \\
\hline & & Pekerjaan sesuai target yang direncanakan & 206 & $\begin{array}{l}\text { Sangat } \\
\text { Tinggi }\end{array}$ \\
\hline \multirow[t]{3}{*}{2} & \multirow{3}{*}{$\begin{array}{l}\text { Quality of } \\
\text { Work }\end{array}$} & Kepuasan atas hasil kerja & 182 & Tinggi \\
\hline & & Kesesuaian tugas dengan perintah & 195 & Tinggi \\
\hline & & Kesesuaian tugas dengan prosedur kerja & 190 & Tinggi \\
\hline \multirow[t]{3}{*}{3} & $\begin{array}{l}\text { Job } \\
\text { Knowledge }\end{array}$ & Pengetahuan terhadap tugas & 194 & Tinggi \\
\hline & & Pengetahuan terhadap lingkungan kerja & 199 & Tinggi \\
\hline & & Pengetahuan tentang prosedur kerja & 198 & Tinggi \\
\hline \multirow[t]{2}{*}{4} & \multirow[t]{2}{*}{ Creativeness } & Kemampuan berkreatifitas & 208 & $\begin{array}{l}\text { Sangat } \\
\text { Tinggi }\end{array}$ \\
\hline & & Dapat diandalkan dalam pekerjaan & 192 & Tinggi \\
\hline \multirow[t]{2}{*}{5} & \multirow[t]{2}{*}{ Cooperation } & Kerjasama dengan pimpinan & 206 & $\begin{array}{l}\text { Sangat } \\
\text { Tinggi }\end{array}$ \\
\hline & & Kerjasama dengan rekan kerja & 204 & $\begin{array}{l}\text { Sangat } \\
\text { Tinggi }\end{array}$ \\
\hline \multirow[t]{3}{*}{6} & \multirow[t]{3}{*}{ Dependability } & Kemampuan mengambil keputusan & 198 & Tinggi \\
\hline & & Kemampuan menyesuaikan diri & 194 & Tinggi \\
\hline & & Berani mengambil resiko & 189 & Tinggi \\
\hline \multirow[t]{2}{*}{7} & \multirow[t]{2}{*}{ Initiative } & Mencari solusi masalah kerja & 192 & Tinggi \\
\hline & & Kesadaran pada tugas yang dibebankan & 192 & Tinggi \\
\hline 8 & $\begin{array}{l}\text { Personal } \\
\text { Qualities }\end{array}$ & $\begin{array}{l}\text { Kemampuan dalam berbagai bidang } \\
\text { pekerjaan }\end{array}$ & 188 & Tinggi \\
\hline
\end{tabular}

Sesuai tabel di atas dapat diketahui bahwa terdapat lima indikator yang mendapatkan skor pada rentang skala 202 - 240,4 dengan kategori sangat tinggi. Sedangkan indikator lainnya berada pada rentang skala 163,5 - 201,9 dengan kategori tinggi. Sehingga rata-rata indikator pada variabel kinerja pegawai berada pada kualifikasi tinggi. Maknanya adalah seluruh pegawai Balai Diklat Aparatur Kementerian Kelautan dan Perikanan memiliki kinerja yang sudah memadai namun masih perlu ditingkatkan.

\subsection{Analisis Verifikatif}

\subsubsection{Koefisien Korelasi}

Perhitungan koefisien korelasi pada penelitian ini menggunakan program SPSS. Dengan menggunakan program SPSS selain dapat menghasilkan nilai koefeisien korelasi namun juga menghasilkan nilai signifikansi korelasi antara 
variabel kecerdasan emosi dan kecerdasan spiritual. Hasil perhitungan dengan program SPSS tersebut seperti pada tabel berikut ini :

Tabel 5. Koefisien Korelasi Antar Variabel

Correlations

\begin{tabular}{|ll|r|r|}
\hline & & $\begin{array}{c}\text { KECERDASA } \\
\text { NEMOSI }\end{array}$ & $\begin{array}{r}\text { KECERDASA } \\
\text { N SPIRITUAL }\end{array}$ \\
\hline KECERDASAN EMOSI & Pearson Correlation & 1 & $.712^{\prime \prime}$ \\
& Sig. (2-tailed) & & .000 \\
& $\mathrm{~N}$ & 48 & 48 \\
\hline KECERDASAN & Pearson Correlation & $.712^{\prime \prime}$ & 1 \\
SPIRITUAL & Sig. (2-tailed) & .000 & \\
& $\mathrm{~N}$ & 48 & 48 \\
\hline
\end{tabular}

*. Correlation is significant at the 0.01 level (2-tailed).

Sesuai tabel di atas dapat diketahui bahwa koefisien korelasi antara kecerdasan emosi dan kecerdasan spiritual sebesar 0,712. Koefisien korelasi tersebut bernilai positif dan dua arah. Sedangkan nilai signifikansi pada tabel di atas menunjukkan angka sebesar 0,00. Besaran nilai signifikansi tersebut akan memberikan makna bagi hubungan kedua variabel tersebut apabila telah dikonsultasikan dengan nilai $\alpha$.

\subsubsection{Koefisien Jalur}

Berdasarkan hasil perhitungan dengan menggunakan program SPSS diperoleh besaran koefisien jalur seperti yang dijelaskan pada tabel di bawah ini :

Tabel 6. Nilai Koefisien Jalur

Coefficients ${ }^{3}$

\begin{tabular}{|c|c|c|c|c|c|c|}
\hline \multirow[b]{2}{*}{ Madel } & & \multicolumn{2}{|c|}{ Unstandardized Coefficients } & \multirow{2}{*}{$\begin{array}{c}\begin{array}{c}\text { Standardized } \\
\text { Coefficients }\end{array} \\
\text { Beta } \\
\end{array}$} & \multirow[b]{2}{*}{ t } & \multirow[b]{2}{*}{ Siq. } \\
\hline & & B & Std. Error & & & \\
\hline 1 & (Constant) & 19.837 & 6.164 & & 3.218 & .002 \\
\hline & KECERDASAN EMOSI & .508 & .250 & .324 & 2.034 & .048 \\
\hline & $\begin{array}{l}\text { KECERDASAN } \\
\text { SPIRITUALL }\end{array}$ & .459 & .189 & .388 & 2.433 & .019 \\
\hline
\end{tabular}

a. Dependent Variable: KINERJA PEGAWAI

Tabel di atas menggambarkan hasil perhitungan koefisien jalur yang bermakna bahwa kecerdasan emosi mempunyai koefisien jalur sebesar 0,508 dan kecerdasan spiritual memiliki koefisien jalur sebesar 0,459. Tabel tersebut juga menunjukkan besaran nilai signifikansi dari kecerdasan emosi sebesar 0,048 dan kecerdasan spiritual sebesar 0,19. Sedangkan untuk besaran pengaruh dari kecerdasan emosi dan kecerdasan spiritual terhadap kinerja pegawai baik pengaruh langsung maupun pengaruh tidak langsung dapat di lihat pada tabel berikut ini : 
Tabel 7

Perhitungan Pengaruh langsung dan pengaruh tidak langsung

\begin{tabular}{|c|c|c|c|}
\hline No & Variabel & Pengaruh Langsung & $\begin{array}{c}\text { Pengaruh Tidak } \\
\text { Langsung }\end{array}$ \\
\hline 1 & Kecerdasan Emosi & $\begin{array}{l}(0,508 \times 0,508) \times 100 \%= \\
25,80 \%\end{array}$ & \multirow{2}{*}{$\begin{array}{c}(0,508 \times 0,459 \times \\
0,712) \times 100 \%= \\
16,60 \%\end{array}$} \\
\hline 2 & $\begin{array}{l}\text { Kecerasan } \\
\text { Spiritual }\end{array}$ & $\begin{array}{l}(0,459 \times 0,459) \times 100 \%= \\
21,06 \%\end{array}$ & \\
\hline
\end{tabular}

Berdasarkan tabel di atas, dapat diketahui besaran pengaruh parsial dan simultan dari variabel bebas $(\mathrm{X})$ terhadap variabel terikat $(\mathrm{Y})$. Besaran pengaruh parsial dan simultan tersebut seperti pada tabel di bawah ini :

\section{Tabel 8}

Besaran Pengaruh Parsial dan Simultan Variabel Bebas

Terhadap Variabel Terikat

\begin{tabular}{|c|c|c|c|c|}
\hline No & Variabel X & $\begin{array}{c}\text { Pengaruh } \\
\text { Langsung (\%) }\end{array}$ & $\begin{array}{c}\text { Pengaruh Tidak } \\
\text { Langsung }(\%)\end{array}$ & $\begin{array}{c}\text { Jumlah } \\
(\%)\end{array}$ \\
\hline 1 & Kecerdasan Emosi & 25,80 & 8,30 & 34,10 \\
\hline 2 & Kecerdasan Spiritual & 21,06 & 8.30 & 29,36 \\
\hline & Total & 46,86 & 16,60 & 63,46 \\
\hline
\end{tabular}

Sesuai tabel di atas diketahui bahwa besaran pengaruh kecerdasan emosi sebesar 25,80\% dan besaran pengaruh kecerdasan spiritual sebesar 21,06. Dalam tabel tersebut juga diketahui besaran pengaruh simultan variabel kecerdasan emosi dan kecerdasan spiritual terhadap kinerja pegawai sebesar $63,46 \%$.

\subsubsection{Pengujian Hipotesis}

\section{a. Uji Hipotesis Korelasi Kecerdasan Emosi $\left(\mathbf{X}_{1}\right)$ dan Kecerdasan Spiritual} $\left(\mathbf{X}_{2}\right)$

Sesuai hasil perhitungan dengan program spss diperoleh nilai siginifikansi korelasi antara kecerdasan emosi dan kecerdasan spiritual sebesar 0,00. Sehingga apabila dikonsultasikan dengan $\alpha$ sebesar 0,05 maka $0,00<\alpha(0,05)$. Dengan demikian maka $\mathrm{H}_{0}$ di tolak, artinya terdapat hubungan yang signifikan antara kecerdasan emosi dan kecerdasan spiritual.

\section{b. Uji Hipotesis Pengaruh Kecerdasan Emosi $\left(X_{1}\right)$ dan Kecerdasan Spiritual $\left(\mathrm{X}_{2}\right)$ secara Parsial terhadap Kinerja Pegawai $(\mathrm{Y})$}

Sesuai hasil perhitungan dengan program spss dapat diketahui pengaruh kecerdasan emosi dan kecerdasan spiritual secara parsial terhadap kinerja pegawai. Hasil perhitungan menunjukkan bahwa nilai signifikansi kecerdasan emosi dan kecerdasan spiritual sebesar 0,048 dan 0,019. Sehingga apabila dikonsultasikan dengan $\alpha$ sebesar 0,05, maka 0,048< $\alpha(0,05)$ dan 0,019< $\alpha$ $(0,05)$. Dengan demikian maka $\mathrm{H}_{0}$ di tolak, artinya terdapat pengaruh yamg 
signifikan dari kecerdasan emosi terhadap kinerja pegawai dan terdapat pengaruh yang signifikan dari kecerdasan spiritual terhadap kinerja pegawai.

\section{c. Uji Hipotesis Pengaruh Kecerdasan Emosi $\left(\mathbf{X}_{1}\right)$ dan Kecerdasan Spiritual}

$\left(\mathrm{X}_{2}\right)$ secara simultan terhadap Kinerja Pegawai $(\mathrm{Y})$

Sesuai hasil perhitungan dengan program spss dapat diketahui pengaruh kecerdasan emosi dan kecerdasan spiritual secara simultan terhadap kinerja pegawai. Hasil perhitungan dengan program spss menunjukkan bahwa nilai signifikansi pada uji F kecerdasan emosi dan kecerdasan spiritual secara simultan terhadap kinerja pegawai sebesar 0,00 . Sehingga apabila dikonsultasikan dengan $\alpha$ sebesar 0,05 , maka $0,00<\alpha(0,05)$. Dengan demikian maka $\mathrm{H}_{0}$ di tolak, artinya terdapat pengaruh yamg signifikan dari kecerdasan emosi dan kecerdasan spiritual secara simultan terhadap kinerja pegawai.

\section{Pembahasan Hasil Penelitian}

\subsection{Pembahasan Hasil Penelitian Deskriptif}

Pembahasan secara deskriptif sesuai hasil penelitian di atas dapat dijelaskan sebagai berikut :

a. Variabel kecerdasan emosi pada penelitian ini memperoleh rata-rata skor 194,4 berada direntang skala 163,5 - 201,9. Artinya bahwa pegawai Balai Diklat Aparatur Kementerian Kelautan dan Perikanan memiliki kecerdasan emosi yang tinggi. Namun dari hasil penelitian, masih tedapat indikator yang perlu ditingkatkan meliputi: pengendalian diri, motivasi, empati dan keterampilan social.

b. Variabel kecerdasan spiritual pada penelitian ini memperoleh rata-rata skor 197,1 berada direntang skala 163,5 - 201,9. Artinya bahwa pegawai Balai Diklat Aparatur Kementerian Kelautan dan Perikanan memiliki kecerdasan spiritual yang tinggi. Namun dari hasil penelitian, masih tedapat indikator yang perlu ditingkatkan meliputi:kemampuan untuk mengatasi permasalahan, kemampaun bersikap positif, kemampuan berfikir rasional, dan kemampuan untuk terus berbuat kebaikan.

c. Kinerja Pegawai pada penelitian ini memperoleh rata-rata skor 196,1 berada direntang skala 163,5 - 201,9. Artinya bahwa pegawai Balai Diklat Aparatur Kementerian Kelautan dan Perikanan memiliki kinerja yang tinggi. Namun kinerja yang sudah tinggi ini dianggap belum maksimal. Hal ini sesuai dengan latar belakang permasalahan pada penelitian ini bahwa masih perlu dilakukan peningkatan kinerja pegawai. Berdasarkan hasil penelitian, indikator-indikator yang masih perlu ditingkatkan meliputi : Kualitas pekerjaan, pengetahuan terhadap pekerjaan,kemampaun pengambilan keputusan, inisiatif dalam pekerjaan dan kemampuan menyelesaikan pekerjaan.

\subsection{Pembahasan Hasil Penelitian Verifikatif}

Pembahasan hasil penelitian secara verifikatif dapat diuraikan sebagaimana berikut : 
a. Pada penelitian ini menunjukkan bahwa hubungan antara variabel kecerdasan emosi dan kecerdasan spiritual sebesar sebesar 0,712 yang positif dan dua arah, termasuk hubungan yang kuat dan positif dua arah. Artinya bahwa apabila kecerdasan emosi meningkat maka kecerdasan spiritual pegawai juga akan meningkat.

b. Pada penelitian ini diperoleh pengaruh kecerdasan emosi yang signifikan terhadap kinerja pegawai sebesar 25,80\% dan pengaruh kecerdasan spiritual yang signifikan terhadap kinerja pegawai sebesar 21,06\%. Artinya bahwa, kecerdasan emosi dan kecerdasan spiritual secara meyakinkan mampu memberikan pengaruh terhadap kinerja pegawai. Sehingga apabila akan meningkatkan kinerja pegawai dapat dilakukan dengan cara meningkatkan kecedasan emosi dan kecerdasan spiritual pegawai. Dari penelitian ini juga menunjukan bahwa kecerdasan emosi memiliki pengaruh yang lebih besar dibandingkan kecerdasan spiritual.

c. Pada penelitian ini diperoleh total pengaruh kecerdasan emosi dan kecerdasan spiritual terhadap kinerja pegawai sebesar 63,46\%. Hasil penelitian ini menunjukkan bahwa masih terdapat faktor yang tidak diteliti namun memiliki pengaruh terhadap kinerja pegawai sebesar 36,54\%. Faktor lain tersebut dapat terdiri dari dari kompensasi, disiplin, kompetensi, budaya kerja, beban kerja, penempatan pegawai, dan peran kepemimpinan.

\section{Simpulan dan Saran}

\subsection{Simpulan}

Berdasarkan hasil penelitian dan pembahasan, maka dapat diperoleh beberapa kesimpulan sebagai berikut:

a. Kecerdasan emosi, kecerdasan spiritual dan kinerja pegawai berada pada rentang skala tinggi.

b. Terdapat hubungan yang signifikan antara kecerdasan emosi dan kecerdasan spiritual, sehingga apabila kecerdasan emosi meningkat maka kecerdasan spiritual akan meningkat.

c. Terdapat pengaruh signifikan kecerdasan emosi terhadap kinerja pegawai sebesar $34,10 \%$ dan terdapat pengaruh signifikan kecerdasan spiritual terhadap kinerja pegawai sebesar 29,36\%.

d. Terdapat pengaruh signifikan kecerdasan emosi dan kecerdasan spiritual secara simultan terhadap kinerja pegawai sebesar $63,46 \%$.

\subsection{Saran}

Berdasarkan hasil penelitian dan pembahasan, maka saran yang dapat disampaikan dalam penelitian ini adalah sebagai berikut:

a. Meningkatkan kecerdasan emosi pegawai agar lebih mampu mengendalikan diri, meningkatkan motivasi, empati dan keterampilan sosial melalui pelatihan-pelatihan berbasis soft skills baik yang diselenggarakan pemerintah maupun pihak swasta.

b. Meningkatkan kecerdasan spiritual pegawai agar mampu mengatasi setiap permasalahan, mampu bersikap positif, rasional, dan terus berbuat kebaikan melalui pelatihan berbasis soft skills 
c. Meningkatkan kecerdasan emosi dan kecerdasan spiritual pegawai melalui pemberian arahan oleh pimpinan pada saat pelaksanaan apel pagi dan melaksanakan kegiatan keagamaan secara bersama-sama.

\section{DAFTAR PUSTAKA}

\section{Buku}

Agustian, Ary Ginanjar.2006. Rahasia Sukses Membangun Kecerdasan Emosi dan Spiritual. Jakarta: Arga.

Aziz, Rahmat dan Mangestuti, Retno.2006. Tiga Jenis Kecerdasan dan Agresivitas Mahasiswa Universitas Islam Negeri Malang. Psikologika. Nomor 21 tahun XI Jan 2006, hal 67-77

Cooper, Robert K dan Sawaf, Ayunan.2002.Executive EQ : Kecerdasan Emosional dalam kepemimpinan dan organisasi. Alih Bahasa: Ales Tri Kantjono Widodo. Jakarta: PT. Gramedia Pustaka Utama

Covey. R.S.2005. The 8th Habbits: Melampaui Efektifitas, Menggapai Keagungan. Jakarta: PT Gramedia Pustaka Utama

Goleman, Daniel.2000. Kecerdasan Manusia. Jakarta: Scholastic

Goleman, Daniel.2003.Kecerdasan Emosional, terj. T. Hermaya, Cet. XIII, Jakarta: Gramedia Pustaka Utama

Goleman, Daniel.2000. Kecerdasan Manusia. Jakarta: Scholastic

Gomes, F. Cardoso.(2003). Sumber Daya Manusia Perkebunan dalam Perspektif. Yogyakarta : Penerbit Ghalia Indonesia

Junedi.2016.Pengaruh Kecerdasan Spiritual,Disiplin Kerja dan Lingkungan Kerja Terhadap Kinerja Pegawai Pada Kantor Kesyahbandaran dan Otoritas Pantoloan. e Jurnal Katalogis Volume 4 Nomor 3

Mangkunegara, Anwar P. 2005. Manajemen Sumber daya Manusia Perusahaan. Bandung : PT Remaja Rosdakarya

Nasution, M. Nur. 2005. Manajemen Mutu Terpadu. Jakarta : Ghalia Indonesia

Purwanto, A.B.2015.Pengaruh Motivasi dan Kecerdasan Emosional Terhadap Kinerja Pegawai. Buletin Bisnis dan Manajemen

Rivai, Veithzal. 2004. Manajemen Sumber Daya Manusia Untuk Perusahaan : Dari Teori Ke Praktik. Jakarta : PT. Raja Grafindo Persada

Zohar, Danah \& Marshall, Ian. 2007. Kecerdasan Spiritual (SQ) Memanfaatkan Kecerdasan Spiritual Dalam Berpikir Integralistik dan Holistik Untuk Memaknai Kehidupan. Bandung: Mizan

Undang-Undang

Undang-Undang Nomor 25 tahun 2009 tentang Pelayanan Publik 